\title{
Organizational Leadership And Subordinate Effect In Utah's Certified Public Accounting Profession
}

Jeffrey N. Barnes, Southern Utah University, USA

David S. Christensen, Southern Utah University, USA

Tyler Stillman, Southern Utah University, USA

\begin{abstract}
Using the Multifactor Leadership Questionnaire (Bass and Avolio 2004), we test the correlation of transformational, transactional, and passive-avoidant leadership styles to subordinate perceptions of workplace efficiency, effectiveness, and satisfaction. Results, from a convenience sample of 103 accounting professionals in 11 CPA firms in Utah, show that transformational leadership has the largest positive correlation. Transactional leadership is less positively correlated. The passiveavoidant style is negatively correlated. Recommendations for implementing transformational leadership are provided.
\end{abstract}

Keywords: Accounting Profession; Leadership; Multifactor Leadership Questionnaire; Subordinate Effect; Efficiency; Effectiveness; Satisfaction

\section{INTRODUCTION}

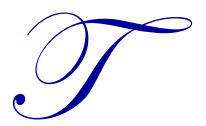

he core purpose of leadership is influencing individuals and groups within an organization (Nahavandi, 2006). The definition of effective leadership varies substantially, and includes increasing individual and group performance (Hui et al., 2007), follower satisfaction (Conger, Kanungo \& Menon, 2000; Stringer, 2006), and effective organizational change (Bass, 1985; Watkins, 2009). Although leadership has many definitions, all have the common thread of influencing others to accomplish organizational objectives.

Defining leadership is only part of understanding the complexities of leadership. Northouse (2010) identified no fewer than 10 leadership approaches or theories to explain leadership manifestations (i.e., trait approach, skills approach, style approach, situational approach, contingency theory, path-goal theory, leadermember theory, exchange theory, transformational theory, and authentic leadership theory). In general, leaders use a combination of traits, attributes, behaviors, and specialized knowledge to influence organizational individuals to accomplish goals (Zenger \& Folkman, 2010). A particularly successful theory of leadership is the full-range leadership theory (Lowe, Avolio, \& Dumdum, 2013).

\section{Full-Range Leadership Theory Styles}

The full-range leadership theory (FRLT) is an especially useful characterization of leadership styles (Bass \& Avolio, 1994) and it is one that many researchers rely upon. Consisting of transformational, transactional, and passive-avoidant leadership styles, the FRLT is a continuum describing the range of leadership styles exhibited by organizational leaders (Lowe, Kroeck, \& Sivasubramaniam, 1996). A leader does not uniquely exhibit one certain leadership style across all situations; rather, situational factors can influence which leadership style is more appropriate. However, individual differences in leadership style are relatively stable over time. 


\section{Transformational Leadership}

Transformational leadership influences subordinates through inspirational charisma, is considerate of the subordinates' concerns, encourages creative solutions and innovation from subordinates, and motivates subordinates to superior performance (Bass, 1985). Transformational leadership is thought most effective in organizations that experience change or are confronting significant uncertainty. Transformational leaders demonstrate an ability to motivate employees in a superior manner (Bryant, 2003). The second leadership style is transactional leadership.

\section{Transactional Leadership}

Transactional leadership is effective in workplace circumstances that possess routinized functions and in which it is necessary to complete tasks on schedule. This leadership style encourages through contingent reward systems with subordinates and manages progress through active supervisor oversight. Transactional leaders tend to create interpersonal relationships through self-interest exchange transactions. Transactional leaders do not generally expect their subordinates to achieve beyond initial expectations, deviate from status quo procedures, nor provide creative solutions (Jung, 2001). Transactional leaders tend to operate more effectively in environments characterized by stability and predictability (De Hoogh, Den Hartog, \& Koopman, 2005). The third leadership style is passive-avoidant leadership.

\section{Passive-Avoidant Leadership}

Passive-avoidant leadership is a dimension of leadership marked by disengagement from followers. Passive leadership avoids conflicts and problem solving, is typically absent from subordinates' concerns and needed guidance, and only becomes involved when absolutely necessary (Antonakis \& House, 2002). Avoidant leadership tendency is sometimes referred to as laissez-faire leadership.

Relating these three leadership styles together, Bass (1997) stated, "Transformational leadership tends to be more effective and satisfying than contingent rewarding, contingent rewarding is more effective and satisfying than managing by exception, and managing by exception is more effective and satisfying than laissez-faire leadership" (p. 137). Leadership appears to influence organizational efficiency, effectiveness, and satisfaction.

\section{Leadership's Influence on Organizational Efficiency, Effectiveness, and Job Satisfaction}

A single industry representative study, of military personnel trained in transformational leadership, reported higher positive correlations to subordinates' performance than the control group (Dvir, Avolio, and Shamir, 2002). Dumdum, Lowe, and Avolio (2002) performed a meta-analytic study and reported transformational leadership was shown to be highly correlated to organizational effectiveness and job satisfaction "over a broad range of organizational settings" (p. 35). The Dumdum, Lowe, and Avolio meta-analytic project reviewed over 100 industry leadership studies, since 1995. They found 49 studies that met their criteria for inclusion, which criteria are the same as this study: the use of the Multifactor Leadership Questionnaire (MLQ) instrument, a reported measure of leader effectiveness, a reported Pearson correlation coefficient, and the leader must have been a direct leader for the subordinate/survey respondent. The MLQ measures the survey respondent's perceptions about the leader's contributions to workplace efficiency, effectiveness, and job satisfaction.

Efficiency is addressed in three MLQ questions. These three questions draw out survey respondents' perceptions about their focal leader getting them to do more than they expected to do, heightening their desire to succeed, and increasing their willingness to try harder. Effectiveness is handled in four MLQ questions. These four questions solicit the survey respondents' perceptions about their focal leader's effectiveness in meeting their jobrelated needs, representing them to higher authority, meeting organizational requirements, and leading a group that is effective. Job satisfaction is asked about in two MLQ questions. These two questions request survey respondents' perceptions about whether their focal leader uses methods of leadership that are satisfying and whether the leader works with them in a satisfactory way (Avolio, Bass, Walumbwa, \& Zhu, 2004). A recent review of the literature finds that empirical studies correlating full-range leadership theory model with "effectiveness outcomes continue to accelerate" (Lowe, Avolio, and Dumdum, 2013, p. 74). 


\section{Transformational Leadership in the Public Accounting Profession}

Earlier, Friedman, Langbert, and Giladi (2000) called for the accounting profession in the United States to embrace the transformational leadership style. A few years later, Mannarelli (2006) described how the Charter Accountants of Ireland had teamed up with INSEAD, a global-leading business school, to help launch a program of leadership training to instill the traits, skills, and behaviors that are associated with transformational leadership. The 2000 AICPA Vision Project emphasized the necessity for the "CPA to develop the leadership skills necessary to influence, inspire, and motivate others to achieve results" (Viator, 2001, p. 100). The AICPA's newly released CPA Horizons 2025 Report continues to emphasize, in their core competencies, transformational leadership attributes and behaviors (AICPA, 2013).

Although transformational leadership is growing in general acceptance as a preferred leadership style, empirical studies using the Multifactor Leadership Questionnaire (MLQ) are difficult to find for the public accounting profession. Additionally, finding any empirical study determining that transformational leadership is more highly correlated to the CPA firm subordinates' perceptions of workplace efficiency, effectiveness, and job satisfaction is rarer, this is a "hole in the literature" (personal conversation with Dr. Rex Dumdum, of Marywood University, April 15, 2013).

\section{MLQ Research Studies of the Public Accounting Profession Continues to be Relatively Sparse}

A shift in research to more narrow or granular components of leadership's influence on subordinates has arisen from 2002 through today. The research has broken into neo-charismatic transformational leadership studies, expanded into research about mediators and moderators through which transformational leadership is transmitted, branched into studies comparing personality traits and behaviors to transformational leadership, and broken into studies measuring gender differences, among other narrowly focused studies (Lowe, Avolio, and Dumdum, 2013). This research expansion, for transformational leadership, is an indication of the maturing leadership topic in the research lifecycle. However, the lack of research findings from the public accounting profession is problematic. Those missing research "bricks," for the public accounting profession, need to be mortared into the wall of knowledge.

From the limited research in the accounting profession, it appears that the transformational leadership style is the preferred style to work under and is the leadership style to emulate (Early \& Davenport, 2010). However, we found no peer-reviewed empirical evidence linking accounting firms' transformational leadership style to differential employee performance regarding perceptions of workplace efficiency, effectiveness, and satisfaction. We sought to determine whether transformational leadership, within the accounting profession, leads to higher employee perceptions of workplace efficiency, effectiveness, and satisfaction, as measured by Bass and Avolio's (2004) Multifactor Leadership Questionnaire.

\section{METHODOLOGY}

Web-based MLQ surveys were administered to accounting firm employees, of an acceptable sample size for organizations classified as small- to regionally-sized public accounting firms in Utah. The study describes the relationship between accounting subordinates' perception of their immediate leader's full-range leadership theory (FRLT) style (Antonakis \& House, 2002; Bass, 1985) to the subordinates' perception of their own workplace efficiency, effectiveness, and satisfaction. The study used the Multifactor Leadership Questionnaire (MLQ) for Research Web Data Collection (Bass \& Avolio, 2004).

\section{Overview}

The purpose of this study was to examine the degree to which public accounting firm's leadership styles are associated with subordinates' perception of their focal leader's influence on workplace efficiency, effectiveness, and satisfaction. 


\section{Research Questions}

Professional accounting leaders and business leaders in general seek to understand how best to improve the firm's leadership practices and thus increase overall employee productivity and workplace satisfaction. This study sought to explore answers to the following question: To what degree do partners, managers, and supervisors' various leadership styles potentially influence the subordinate's perception the firm's workplace efficiency, effectiveness, and satisfaction? A variety of hypotheses naturally derive from this research question.

\section{Quantitative Hypotheses}

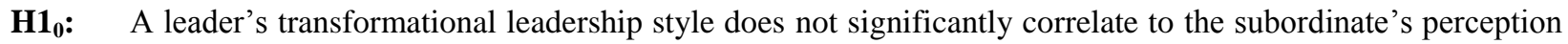
of the firm's workplace efficiency, effectiveness, and satisfaction.

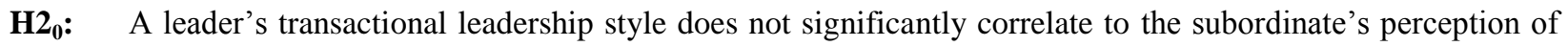
the firm's workplace efficiency, effectiveness, and satisfaction.

$\mathbf{H 3}_{0}$ : A leader's passive-avoidant leadership style does not significantly correlate to the subordinate's perception of the firm's workplace efficiency, effectiveness, and satisfaction.

The alternate hypothesis for each of the three null hypotheses are that certain leadership styles do potentially influence employee perceptions of workplace efficiency, effectiveness, and satisfaction.

\section{Population}

In late 2011, the research was carried out in Utah. Approximately 1,175 certified public accountants (CPAs) were in the practice of public accounting and members of their professional accounting association (Utah's Association of CPAs, 2009). These CPAs worked in a variety of different-sized firms, ranging from sole proprietorships to large professional international corporations. The number of CPAs per firm range from one to scores of CPAs, within a single geographically located office. There were 469 separate physical CPA firm offices in this Utah at the time of the study, many with less than five CPAs. Of the 469 firms, only 41 firms had more than five CPAs or professional staff tracked to become CPAs.

\section{Target Population}

For this study, a relationship needed to exist between a subordinate and immediate focal leader or supervisor because it is within those leader/subordinate relationships that perceptions of firm's workplace efficiency, effectiveness, and satisfaction occur. Figure 1 shows the minimum practice structure sought for by this study.

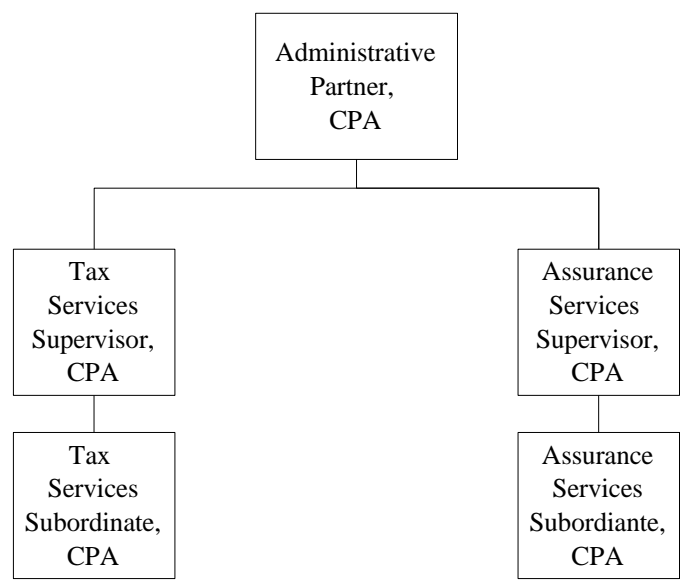

Figure 1. Minimum Practice Structure Sought from Population 
Firms with five or more CPAs, or professional staff tracked to become CPAs were deemed an acceptable target population firm from which to draw a sample. Firms with 5 or more CPAs were able to identify which service function they more often worked, such as, tax, assurance services, or other engagements. Firms with such varied practice specialized professionals had at least two immediate supervisor levels for investigation. At the time of the study, 41 firms with five or more CPAs listed in a professional directory. These 41 firms had 635 CPAs and prospective CPAs. This target population served as the source for the convenience sample.

\section{Convenience Sample Selection}

In late 2011, after initially telephoning and communicating with each of the 41 identified CPA firms with 5 or more professional staff, permission was received to contact organizational leadership for permission to conduct the surveys. After sending a packet of information and instructions about the proposed research, $11 \mathrm{CPA}$ firms provided written permission to contact organization personnel, via email, for the administration of the electronic research survey. After three email requests, these $11 \mathrm{CPA}$ firms provided 103 usable responses, garnering a $43.6 \%$ response rate.

\section{Informed Consent and Confidentiality}

After having received a signed authorization letter from each participating CPA firm, we electronically sent each prospective participant an introductory letter and an informed consent form. The informed consent letter communicated that participation was voluntary, replies would be kept confidential, names of non-participants would not be disclosed, and all data from the surveys would be coded to eliminate the risk of identifying any single participant or firm. All those who participated signed and returned the electronic informed consent form.

\section{Theoretical Model Design}

This study used a published instrument for measuring the independent variables of leadership style and the dependent variables of subordinates' perception of workplace efficiency, effectiveness, and satisfaction. Figure 2, provides a diagram of the proposed independent and dependent variables found in the integrated leadership and subordinate effect framework.

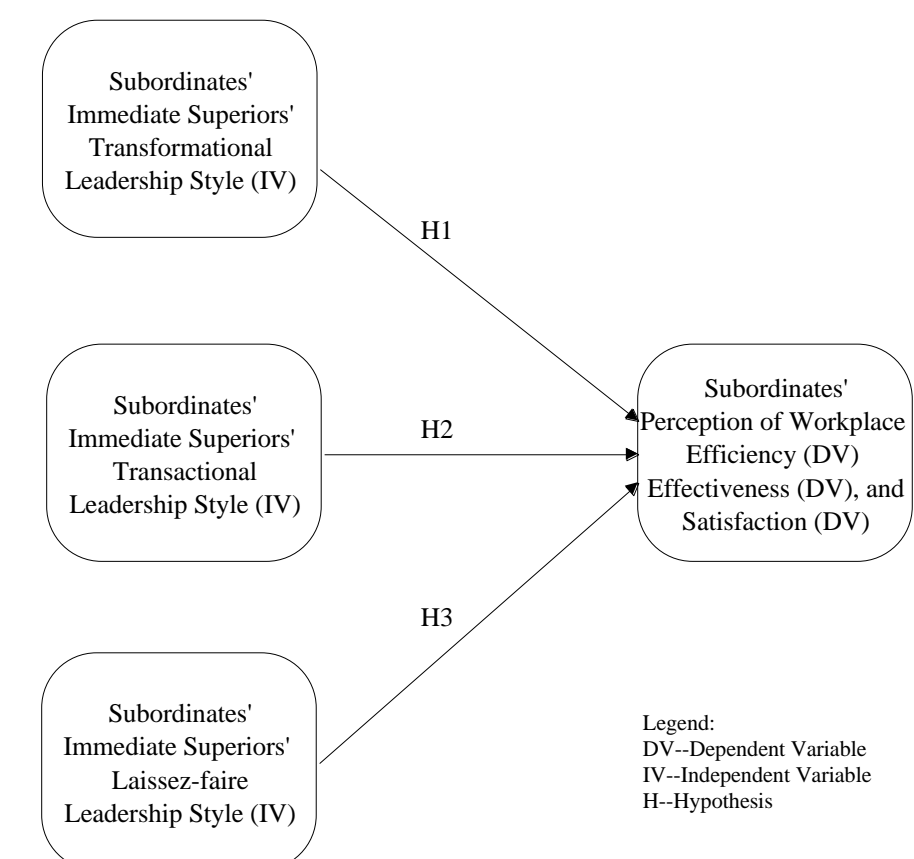

Figure 2. Conceptual Leadership and Subordinate Effect Framework Overview of the Design Appropriateness 
This quantitative research study, with a correlation design, investigated the relationships between independent and dependent variables (Creswell, 2005). To answer this study's research question, survey respondents selected discrete Likert-type scale choices, thus providing quantifiable data to measure the degree of their perceptions and correlative association among the variables. The public accounting subordinates quantified (i.e., Scale $0=$ Not at all, to $4=$ Frequently, if not always) their immediate focal leader's full-range leadership style, which could be transformational (IV), transactional (IV), or passive-avoidant (IV) (Antonakis \& House, 2002). The public accounting subordinate then quantified (i.e., Scale $0=$ Not at all, to $4=$ Frequently, if not always) their own perception of the accounting firm's workplace efficiency (DV), effectiveness (DV), and satisfaction (DV) factors.

\section{Validity and Reliability of MLQ}

Mind Garden, Inc. stated that since the MLQ, Form 5X was developed in 1995, “. . . it has been used in nearly 300 research programs, dissertations and masters' theses around the globe" (MLQ, 2004, p. 33). In assessing the MLQ's operational validity, meta-analysis reviews in the military and in the wider organizational psychology literature have established that the transformational leadership and the rated and objectively measured performance criteria (i.e., workplace efficiency, effectiveness, and satisfaction) were more positive and stronger than with the transactional styles of leadership and the less active passive-avoidant leadership style (Dum dum, Lowe, \& Avolio, 2002; Lowe, Kroeck, \& Sivasubramaniam, 1996).

The MLQ has demonstrated stable factor structure using confirmatory factor analysis in previous studies (Antonakis, Avolio, \& Sivasubramaniam, 2003; Avolio, Bass, \& Jung, 1999; Avolio 2002; Dum dum, Lowe, \& Lowe, Kroeck, \& Sivasubramaniam, 1996; Lowe, Avolio, \& Dumdum, 2013). The Cronbach's alpha reliability coefficient ranges from .60 to .92 (MLQ, 2004). Mind Garden, Inc., the legal entity that sells the use of the MLQ instrument, stated, "For the last 25 years, the MLQ has been the principal means by which we were able to reliably differentiate highly effective from ineffective leaders in military, government, education, manufacturing, high technology, church, correctional, hospital, and volunteer organizations" (MLQ, 2004, p. 12). This study seeks partially to provide additional evidence about the public accounting profession.

\section{RESULTS}

\section{Descriptive Statistics}

Descriptive statistics show personalized information for each survey respondents and their relationship with the CPA firm, in Tables 1 and 2, respectively.

Table 1 Respondents' Personal Information

\begin{tabular}{lccccccc}
\hline \multicolumn{1}{c}{ Age } & Freq. & Gender & Freq. & Educ. & Freq. & CPA? & Freq. \\
\hline 26 & 6 & Female & 29 & AS & 3 & Yes & No \\
$26-40$ & 74 & Male & 74 & BS & 17 & 81 & \\
$41-55$ & 19 & & & MS & JD, etc. & 2 & Total \\
$>55$ & 4 & & & Total & 103 & 103 \\
\hline Total & 103 & Total & 103 & &
\end{tabular}

Table 2 Respondents' Relationship to and CPA Firm Information

\begin{tabular}{lccccccc}
\hline Years With Firm & Freq. & Work Function & Freq. & Respon. Level & Freq. & Firm Size & Freq. \\
\hline $0-2$ & 18 & Assurance & 61 & Partner & 11 & Big 4 & 0 \\
$3-4$ & 27 & Tax & 35 & Manager & 42 & National & 1 \\
$5-10$ & 32 & Consulting & 2 & Supervisor & 31 & Regional & 32 \\
$>10$ & 26 & Other & 5 & Staff & 19 & Local, large & 50 \\
& & & & & & Local, small & 20 \\
\hline Total & 103 & Total & 103 & Total & 103 & \multicolumn{2}{c}{ Total } \\
\hline
\end{tabular}

The state-wide professional accounting socioeconomic parameters are not too dissimilar to the U.S. national population's socioeconomic parameters, for the accounting profession, regarding women (Gold, 2007; Vigilante, 2005) and minorities (Flesher \& Gabre, 2009). 


\section{Means Analysis}

Uniquely provided by this study are the reported differences between Utah's subordinates' perspectives of their focal leaders' leadership style and perceptions of workplace efficiency, effectiveness, and satisfaction. Table 3 provides the sample means for transformational, transactional, and passive-avoidant leadership styles for two groups. The first group (MLQ) represents the data set collected by Avolio and Bass (2004). This data contains 27,285 cases from a variety of U.S. industries and professions, from all employment levels within the reporting organizations. The second group (Current Study) represents this study's 103 cases from all employment levels within the CPA firm's organizational structures.

Table 3 Comparison of Leadership Style Sample Means, Using One-Sample T-Test

\begin{tabular}{|c|c|c|c|c|c|c|}
\hline Leadership Style & $\begin{array}{c}\text { Mean } \\
(\text { MLQ) } \\
(\mathbf{N}=\mathbf{2 7}, 285) \\
\end{array}$ & $\begin{array}{c}\text { Mean } \\
\text { (Current Study) } \\
(\mathbf{N}=\mathbf{1 0 3})\end{array}$ & Difference & $t$ & $d f$ & Sig. (2-tailed) \\
\hline Transformational & 2.85 & 2.53 & -0.32 & -5.119 & 102 & $.000 * *$ \\
\hline Transactional & 2.27 & 2.16 & -.014 & -10.563 & 102 & $.000 * *$ \\
\hline Passive-avoidant & .84 & 1.32 & 0.48 & 7.349 & 102 & $.000 * *$ \\
\hline
\end{tabular}

MLQ Frequency Key: $0.0=$ Not at all, $1.0=$ Once in a while, $2.0=$ Sometimes, $3.0=$ Fairly often, and $4.0=$ Frequently, if not always. $* *$ Criteria $=\mathrm{CI}(.95)$

The one-sample t-test statistic is statistically significant for all three leadership styles. Utah's transformational and transactional leadership styles are significantly lower than the U.S. average and the passive avoidant leadership style is significantly higher than the U.S. average.

Table 4 provides the sample means for the subordinates' perception of their workplace efficiency, effectiveness, and satisfaction, for two groups. The first group (MLQ) represents the data set collected by Avolio and Bass (2004). This data contains 27,285 cases from a variety of U.S. industries and professions, from all employment levels within the reporting organizations. The second group (Current Study) represents this study's 103 cases from all employment levels within the CPA firm's organizational structures.

Table 4 Comparison of Subordinate Effect Criteria, Using One-Sample T-Test

\begin{tabular}{|c|c|c|c|c|c|c|}
\hline Leadership Style & $\begin{array}{c}\text { Mean } \\
(\text { MLQ) } \\
(\mathbf{N}=27,285)\end{array}$ & $\begin{array}{c}\text { Mean } \\
\text { (Current Study) } \\
(\mathbf{N}=\mathbf{1 0 3})\end{array}$ & Difference & $t$ & $d f$ & Sig. (2-tailed) \\
\hline Efficiency & 2.74 & 2.59 & -0.15 & -1.579 & 102 & .117 \\
\hline Effectiveness & 3.07 & 2.78 & -0.29 & -3.468 & 102 & $.001 * *$ \\
\hline Satisfaction & 3.08 & 2.82 & -0.26 & -2.898 & 102 & $.005 * *$ \\
\hline
\end{tabular}

MLQ Frequency Key: $0.0=$ Not at all, $1.0=$ Once in a while, $2.0=$ Sometimes, $3.0=$ Fairly often, and $4.0=$ Frequently, if not always. $* *$ Criteria $=\mathrm{CI}(.95)$

The one-sample t-test statistic is statistically significant for two of the three leadership styles. Utah's subordinates' perceptions of workplace effectiveness and satisfaction are significantly lower than the U.S. average.

\section{Cronbach's Alpha}

Cronbach's alpha was conducted to assess reliability and internal consistency for each of the surveys' scales. For instance, in Table 5, the transformational leadership construct or scale, under the Multifactor leadership Questionnaire (MLQ) has a Cronbach's alpha of .92, or 92\%. The $92 \%$ measurement is the percentage of variability of a composite score explained by the relationship of the 20 questions making up the transformational leadership scale. The higher the Cronbach's alpha calculation, the better the scale is at representing what it purports to represent. The lower the Cronbach's alpha calculation, the less reliable it is to draw associations with the data. For Cronbach's alphas, George and Mallery (2003) suggested the following: “ $>$.9 - Excellent, _> .8 - Good, _ $>.7-$ Acceptable, _> .6-Questionable, _> .5 - Poor, and _<.4-Unacceptable” (p. 231). Cronbach's alpha, calculated on SPSS, for all scales used in this study are listed in Table 5. 
Table 5 Cronbach's Alpha for Surveys' Scales

\begin{tabular}{lccc}
\hline & Survey/Scale & $\begin{array}{c}\text { Cronbach's } \\
\text { alpha }\end{array}$ & $n$ \\
\hline MLQ & & .92 & 20 \\
Transformational & .61 & 8 \\
Transactional & .75 & 8 \\
Passive-avoidant & & 3 \\
Subordinate Effect & .86 & 4 \\
Efficiency & .88 & 2 \\
Effectiveness & .90 & \\
Satisfaction & & \\
\end{tabular}

\section{Correlation Analysis}

The Pearson Correlation $(r)$, significance ( $p$-value), and the number of items in the sample $(N)$, for transformational leadership, are reported in Table 6.

Table 6 Bivariate Correlation Analysis, Transformational Leadership to Efficiency, Effectiveness and Satisfaction Outcome Effects

\begin{tabular}{lccc}
\hline \multicolumn{1}{c}{$\begin{array}{c}\text { Transformational } \\
(\text { IV) }\end{array}$} & $\begin{array}{c}\text { Efficiency } \\
(\mathbf{D V})\end{array}$ & $\begin{array}{c}\text { Effectiveness } \\
(\mathbf{D V})\end{array}$ & $\begin{array}{c}\text { Satisfaction } \\
(\mathbf{D V})\end{array}$ \\
\hline Pearson Correlation $(r)$ & .847 & .835 & .803 \\
Significance (2-tailed), $p$-value & $.000^{* *}$ & $.000^{* *}$ & $.000^{* *}$ \\
$N$ & 103 & 103 & 103 \\
\hline
\end{tabular}

**Correlation is significant at the 0.01 level (2-tailed).

The first null hypothesis states that a leader's transformational leadership style does not significantly correlate to the subordinate's perception of the firm's workplace efficiency, effectiveness, and satisfaction. The bivariate correlation analysis, reported that efficiency, effectiveness, and satisfaction are positively and significantly correlated with transformational leadership at level of significance of $1 \%$ or less. Thus, we reject the null hypothesis and accept the alternate hypothesis that transformational leadership is significantly correlated to subordinates' perception of organizational workplace efficiency, effectiveness, and satisfaction.

The Pearson Correlation $(r)$, significance ( $p$-value), and the number of items in the sample $(N)$, for transactional leadership, are reported in Table 7.

Table 7 Bivariate Correlation Analysis, Transactional Leadership to Efficiency, Effectiveness and Satisfaction Outcome Effects

\begin{tabular}{lccc}
\hline \multicolumn{1}{c}{$\begin{array}{c}\text { Transactional } \\
(\text { IV) }\end{array}$} & $\begin{array}{c}\text { Efficiency } \\
(\mathbf{D V})\end{array}$ & $\begin{array}{c}\text { Effectiveness } \\
(\mathbf{D V})\end{array}$ & $\begin{array}{c}\text { Satisfaction } \\
(\mathbf{D V})\end{array}$ \\
\hline Pearson Correlation $(r)$ & .505 & .474 & .416 \\
Significance (2-tailed), $p$-value & $.000^{* *}$ & $.000^{* *}$ & $.000^{* *}$ \\
$N$ & 103 & 103 & 103 \\
\hline
\end{tabular}

**Correlation is significant at the 0.01 level (2-tailed).

The second null hypothesis states that a leaders' transactional leadership style does not significantly correlate to the subordinate's perception of the firm's workplace efficiency, effectiveness, and satisfaction. The bivariate correlation analysis, reported that efficiency, effectiveness, and satisfaction are positively and significantly correlated with transactional leadership at level of significance of $1 \%$ or less. Albeit, that the transactional correlations are just better than half as strong as correlations found with the transformational leadership style. Thus, we reject the null hypothesis and accept the alternate hypothesis that transactional leadership is significantly correlated to subordinates' perception of organizational workplace efficiency, effectiveness, and satisfaction. 
The Pearson Correlation $(r)$, significance ( $p$-value), and the number of items in the sample $(N)$, for passiveavoidant leadership, are reported in Table 8.

Table 8 Bivariate Correlation Analysis, Transactional Leadership to Efficiency, Effectiveness and Satisfaction Outcome Effects

\begin{tabular}{lccc}
\hline \multicolumn{1}{c}{$\begin{array}{c}\text { Passive-avoidant } \\
(\text { IV) }\end{array}$} & $\begin{array}{c}\text { Efficiency } \\
(\mathbf{D V})\end{array}$ & $\begin{array}{c}\text { Effectiveness } \\
(\text { DV) }\end{array}$ & $\begin{array}{c}\text { Satisfaction } \\
(\text { DV) }\end{array}$ \\
\hline $\begin{array}{l}\text { Pearson Correlation }(r) \\
\text { Significance (2-tailed), } p \text { - }\end{array}$ & -.423 & -.508 & -.468 \\
value & $.000^{* *}$ & $.000^{* *}$ & $.000^{* *}$ \\
$N$ & & & 103 \\
\hline
\end{tabular}

**Correlation is significant at the 0.01 level (2-tailed).

The third null hypothesis states that a leader's passive-avoidant leadership style does not significantly correlate to the subordinate's perception of the firm's efficiency, effectiveness, and workplace satisfaction. The bivariate correlation analysis, reported that efficiency, effectiveness, and satisfaction are negatively and significantly correlated with the independent variable, passive-avoidant leadership, at the level of significance of $1 \%$ or less for efficiency, effectiveness and satisfaction. Thus, we reject the null hypothesis and accept the alternate hypothesis that passive-avoidant leadership is significantly correlated, albeit negatively, to the subordinates' perception of organizational workplace efficiency, effectiveness, and satisfaction.

We found that both transformational and transactional leadership were significantly correlated to efficiency, effectiveness, and satisfaction. That is, correlations for both leadership styles and outcomes were significantly different from zero. However, this does not speak to the questions of whether one leadership style is more highly correlated with outcomes than the other. To determine this, we computed an r-to-z transformation to determine whether transformational leadership style demonstrated a higher correlation with outcomes than transactional leadership style (see Table 9). In all cases the correlation was significantly higher for transformational leadership.

Table $9 \mathrm{R}$ to $\mathrm{Z}$ Transformation between Transformational and Transactional Leadership on Outcomes

\begin{tabular}{lccc}
\hline \multicolumn{1}{c}{$\begin{array}{c}\text { Correlational } \\
\text { Differences }\end{array}$} & $\begin{array}{c}\text { Efficiency } \\
(\mathbf{D V})\end{array}$ & $\begin{array}{c}\text { Effectiveness } \\
(\mathbf{D V})\end{array}$ & $\begin{array}{c}\text { Satisfaction } \\
(\mathbf{D V})\end{array}$ \\
\hline Fisher's Z & 4.88 & 4.87 & 4.70 \\
Significance (2-tailed), $p$-value & $.000 * *$ & $.000 * *$ & $.000^{* *}$ \\
\hline
\end{tabular}

**Z is significant at the 0.01 level (2-tailed).

\section{LIMITATIONS}

Campbell and Stanley (1963) stated that correlation studies seek to expose disconfirmation between variables. Continuing, they stated, "If zero correlation is obtained, the credibility of the hypothesis is lessened. If a high correlation occurs, the credibility of the hypothesis is strengthened in that it has survived a chance of disconfirmation" (p. 64). If correlation exists between two variables, proof of causation is not necessarily established. Valid relationships are supported by extended confirmatory research, over time, and within similar contexts. This study was able to obtain a convenience sample size for 11 CPA firms' amenable to participation. Randomness of sample selection was thus not fully realized. Generalizability is not possible with these results. For future research, obtaining CPA lists from State CPA Societies, of individual CPA members, might provide an approach for a random sample useful for generalizability. Access to larger national and international CPA firms should continue to be pursued. More important, strong academic research relationships should be developed between faculty research members and CPA firm power decision-makers desirous for meaningful statistical results, confidentially prepared and reported.

\section{CONCLUSIONS AND RECOMMENDATIONS}

This research study successfully found confirmatory evidence regarding the effects of leadership style's correlations on subordinates' perceptions of the organizational workplace efficiency, effectiveness, and satisfaction, 
in the public accounting profession. Transformational leadership may influence subordinates to become aware of what is important to the accounting firm, such as performance expectations, as well as convince subordinates to higher levels of moral and ethical standards (Antonakis and House, 2002; MLQ, 2004). Accounting leaders, which employ transformational leadership, exhibit leader idealized attributes, idealized behaviors, inspirational motivation, intellectual stimulation, and individualized consideration. Specifically, some of these attributes and behaviors can be explained as charisma, which instills pride in others, going beyond self-interest for the good of the group, and builds respect. Additionally, Utah's transformational leader speaks optimistically about the future, what needs to be accomplished, articulates a compelling vision of the future, and expresses confidence in the goals to be achieved.

\section{Transformational Leadership Practice Opportunities}

Public accounting firm's organization structure is a classic hierarchical structure. Partners/directors lead managers, managers lead supervisors, and supervisors lead staff. Throughout a given year, accounting firm leaders typically perform numerous singular engagements. Supervisors and staff are the personnel mix that more frequently changes between the various assigned engagements. In Viator's (2001) study, transactional leadership is commonly exhibited with the accounting profession's more routinized service functions, such as, audit and tax services. During these singular engagements, supervisors or focal leaders can practice for themselves and train their subordinates in transformational leadership attributes and behaviors. To increase transformation leadership style's practice and recognition, even among routinized service functions, public accounting leaders may consider incorporating many recommendations listed in Table 10. Turning accounting leader/subordinate professional service engagements into worthwhile training opportunities was suggested by the AICPA's Private Companies Practice Section's 2011 Top Talent Study (El-Ramly, 2011).

Table 10 Transformational Leadership Building Actions or Behaviors

\begin{tabular}{|c|c|c|}
\hline $\begin{array}{l}\text { Transformational } \\
\text { Leadership Style } \\
\text { Scale }\end{array}$ & $\begin{array}{c}\text { Scale Definition } \\
\text { The leader ... }\end{array}$ & $\begin{array}{c}\text { An Example of How an Accounting Firm Leader Could Employ } \\
\text { Transformational Behavior }\end{array}$ \\
\hline \multirow[t]{4}{*}{ Idealized Attributes } & Instills pride & $\begin{array}{l}\text { At the onset, during, and the end of an engagement activity, let your } \\
\text { subordinate know how appreciative you are in leading an engagement } \\
\text { activity with the subordinate and that both should grow from the } \\
\text { experience }\end{array}$ \\
\hline & Goes beyond self-interest & $\begin{array}{l}\text { Always show personal interest in the subordinate's success by } \\
\text { selflessly helping and advising work efficiencies in a timely manner }\end{array}$ \\
\hline & Acts respectfully & $\begin{array}{l}\text { Always act respectfully of others, at all times, and always show } \\
\text { respect to and about the subordinate when interacting with clients or } \\
\text { colleagues }\end{array}$ \\
\hline & Displays confidence & $\begin{array}{l}\text { At an appropriate time, discuss a sense of responsibility and loyalty to } \\
\text { the accounting firm and confidence about the engagement's successful } \\
\text { completion and purpose }\end{array}$ \\
\hline \multirow[t]{4}{*}{$\begin{array}{l}\text { Idealized } \\
\text { Behaviors }\end{array}$} & $\begin{array}{l}\text { Talks about values and } \\
\text { beliefs }\end{array}$ & $\begin{array}{l}\text { During engagement activities' reflective opportunities (i.e, during } \\
\text { meals, reviewing subordinates' work, discussing client difficulties) } \\
\text { share personal company-related, professional-related, or personal- } \\
\text { related values and beliefs }\end{array}$ \\
\hline & $\begin{array}{l}\text { Specifies the importance } \\
\text { of sense of purpose }\end{array}$ & $\begin{array}{l}\text { At appropriate times, express the importance of the professional } \\
\text { accounting profession's responsibility to the public's interest and how } \\
\text { the firm's services add to client efficiencies, compliance, and } \\
\text { sustainability }\end{array}$ \\
\hline & $\begin{array}{l}\text { Considers the moral and } \\
\text { ethical issue }\end{array}$ & $\begin{array}{l}\text { At appropriate times, share your moral/ethical/legal decision-making } \\
\text { processes, compliant with the accounting firm and or profession's } \\
\text { recommended decision-making practices }\end{array}$ \\
\hline & $\begin{array}{l}\text { Emphasizes collective } \\
\text { sense of mission }\end{array}$ & $\begin{array}{l}\text { At the onset of an engagement activity, speak of the importance of } \\
\text { team cohesion, problem-solving agreement, and efficient and } \\
\text { effectively completion of the engagement activity }\end{array}$ \\
\hline
\end{tabular}


Table 10 cont.

\begin{tabular}{|c|c|c|}
\hline \multirow[t]{4}{*}{$\begin{array}{l}\text { Inspirational } \\
\text { Motivation }\end{array}$} & Talks optimistically & $\begin{array}{l}\text { When discussion allows, speak positively about the accounting firm's } \\
\text { future growth opportunities and leadership opportunities for the } \\
\text { subordinate }\end{array}$ \\
\hline & $\begin{array}{l}\text { Talks enthusiastically } \\
\text { work objectives }\end{array}$ & $\begin{array}{l}\text { During each engagement, be enthusiastic about the engagement's } \\
\text { objectives and work tasks to be completed by all involved }\end{array}$ \\
\hline & $\begin{array}{l}\text { Articulates a compelling } \\
\text { vision }\end{array}$ & $\begin{array}{l}\text { When occasion arises, communicate the strategic goals and objectives } \\
\text { of the accounting firm and how the subordinate fits into the future } \\
\text { success of the accounting firm }\end{array}$ \\
\hline & Expresses confidence & $\begin{array}{l}\text { At the onset of the engagement, express the potential work task } \\
\text { difficulties and how the leader and subordinate will work together to } \\
\text { complete the engagement successfully }\end{array}$ \\
\hline \multirow[t]{4}{*}{$\begin{array}{l}\text { Intellectual } \\
\text { Stimulation }\end{array}$} & $\begin{array}{l}\text { Re-examines critical } \\
\text { assumptions }\end{array}$ & $\begin{array}{l}\text { With each engagement, coach the subordinate about how the } \\
\text { engagement procedures can be more efficiently performed, how } \\
\text { worksheets should be organized and designed to evidence procedures } \\
\text { have been properly performed, and how improvements from the prior } \\
\text { engagement can be employed }\end{array}$ \\
\hline & Seeks input & $\begin{array}{l}\text { Always seek subordinate input for solving client engagement } \\
\text { problems that arise }\end{array}$ \\
\hline & $\begin{array}{l}\text { Gets others to innovate } \\
\text { solutions }\end{array}$ & $\begin{array}{l}\text { Coach the subordinate about how to solve client dilemmas, resolve } \\
\text { accounting or tax measurement problems, or use current professional } \\
\text { literature to bring another perspective to solving engagement } \\
\text { difficulties }\end{array}$ \\
\hline & Suggests new approaches & $\begin{array}{l}\text { At the onset of the engagement, coach the subordinate about how up- } \\
\text { line leaders might have changed or reasons for not changing the } \\
\text { engagement approach }\end{array}$ \\
\hline \multirow[t]{4}{*}{$\begin{array}{l}\text { Idealized } \\
\text { Consideration }\end{array}$} & Coaches & $\begin{array}{l}\text { During the whole engagement, the leader should selflessly coach the } \\
\text { subordinate how to improve the craft of performing the required } \\
\text { engagement procedures }\end{array}$ \\
\hline & $\begin{array}{l}\text { Treats others as } \\
\text { contributing individuals }\end{array}$ & $\begin{array}{l}\text { Learn about your subordinate before commencing the engagement. } \\
\text { Learn his/her name, family circumstances or status, interests, and past } \\
\text { performance with an objective of helping the subordinate to improve } \\
\text { KSAs (i.e., knowledge, skills, and abilities) }\end{array}$ \\
\hline & Considers individual needs & $\begin{array}{l}\text { Learn about the subordinate's needs, abilities, and aspirations to better } \\
\text { coach his/her "career equity," so as to assist the subordinate in their } \\
\text { desired career path }\end{array}$ \\
\hline & Develops others & $\begin{array}{l}\text { During the engagement and at the end, assist the subordinate in } \\
\text { developing their strengths with during-the-engagement work practice } \\
\text { recommendations and a meaningful performance evaluation }\end{array}$ \\
\hline
\end{tabular}

Adapted: Scale definitions as adapted from Avolio and Bass, 1999. 
The goal for the accounting profession should be to move transformation leadership traits and behaviors to a more often recognized leadership style, lessen the recognition of the transactional leadership style, and completely eliminate passive-avoidant leadership style. The proposed future theoretical movement of the public accounting profession's leadership most recognized by subordinates is shown in Figure 3.

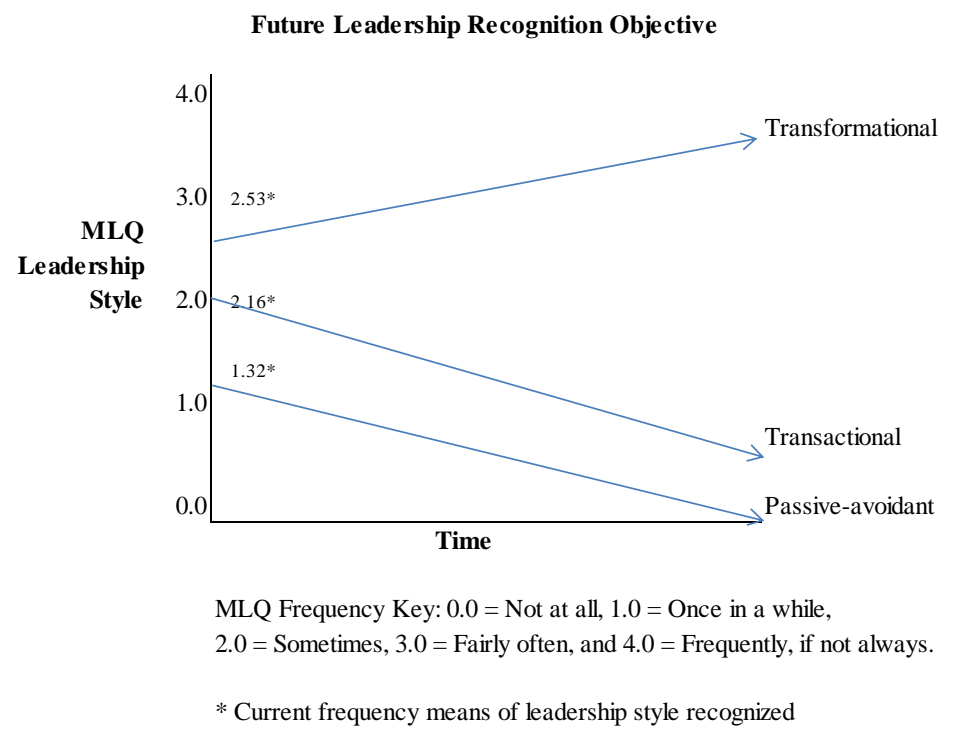

Figure 3. Utah's Public Accounting Profession's Future Leadership Objective

As shown in Figure 3, the objective is not to eradicate transactional leadership style, but rather to lessen its recognition, while enhancing the perception of transformational leadership style. Lessening transactional leadership style behaviors, while enhancing transformational leadership style behaviors can be accommodated by following the recommendations presented in Table 10 (Transformation Building Actions or Behaviors). Many of these transformational actions and behaviors are easily integrated into the daily engagement activities of the professional accounting profession. Aristotle (1962) taught that persons become just by doing just acts, temperate by doing temperate acts, brave by doing brave acts. The more the public accounting leaders practice transformational leadership behaviors, as presented in Table 10, the more likely the public accounting leader becomes a transformational leader.

Transformational leadership style concerning, respectful, loyalty-building and attentive behavior does not require additional leadership time; it takes a change in leadership interpersonal communication approaches. Transformational story-telling about values, beliefs, ethical successes, easily replaces talking about trivial issues; also, opportunities to express enthusiasm for the future or the successful completion of a task, or expressions of confidence are always nearly available with each engagement. Including subordinates in important engagement decisions and kindly sharing how work product working papers can be better designed and organized always are coaching moments present with each engagement. Turning a transactional action into a transformational action is often in how the task requirement is communicated and collaboratively completed. The newer professional subordinate, at every level of the organization, always appreciates selfless coaching by his or her leader. Bending the recognition of the transactional leadership style tendencies down and raising the recognition of the transformational leadership style is caused by a change in the leadership mindset and behaviors.

\section{Changing the Leadership Mindset}

A change in leadership mindset can be accomplished through training interventions and improved process procedures emphasizing transformational leadership attributes and behaviors (Scaletta, 2006). The changing of the leadership mindset must include training emphasizing transformational behaviors. Derue, Nahrgang, Wellman, and Humphrey (2011), through their meta-analysis assessing relative validity of leadership trait and behavior theories, 
stated that ". . . transformational leadership was the most consistent predictor cross the criteria [i.e., leader effectiveness, group performance, follower job satisfaction, and satisfaction with leader]" (p. 37).

To be a process-based management entity, public accounting firms must first (a) become aware that leadership changes are necessary, (b) commit to make leadership changes through executive approved leadership initiatives, (c) engage the whole accounting firm with structural support for the time-requiring transformational activities, as presented in Table 10, (d) ensure that management processes are operational and effective, (e) integrate transformational leadership into the strategy planning of the accounting firm, and (f) embed transformational leadership in its everyday language, presentations, newsletters, etc.

Additionally, each professional accounting firm leader is required to earn sufficient number of continuing professional education (CPE) hours to maintain CPA licensure. The State's accounting profession and firms should encourage taking CPE courses instructing how transformational leadership opportunities exist with the high-pressure and demanding public accounting profession and how transformational leadership knowledge can change into transformational leadership skills and abilities.

\section{AUTHOR INFORMATION}

Jeffrey N. Barnes, DBA, CPA., Associate Professor of Accounting, School of Business, Southern Utah University, 351 West University Blvd., Cedar City, Utah 84720. 1-435-586-5406. He holds a DBA from the University of Phoenix's School of Advanced Studies and MAcc from Brigham Young University. His research interests are leadership, accounting ethics, and professional development. E-mail: barnes@suu.edu (Corresponding author)

David S. Christensen, Ph.D., CMA, CCEA. Professor of Accounting, School of Business, Southern Utah University, 351 West University Blvd., Cedar City, Utah 84720. 1-435-865-8058. He holds a Ph.D. in Accounting from the University of Nebraska, at Lincoln and a MAcc from Utah State University. His research interests are accounting ethics and cost management. E-mail: christensend@ suu.edu

Tyler S. Stillman, Ph.D., Assistant Professor of Management \& Marketing, School of Business, Southern Utah University, 351 West University Blvd., Cedar City, Utah 84720. 1-435-586-1912. He holds a Ph.D. from Florida State University, MS in Social Psychology from Florida State University, and an MA in Psychology from Brigham Young University. His research interests are consumer behavior and leadership. E-mail: tylerstillman@suu.edu

\section{REFERENCES}

1. $\quad$ AICPA. (2013). CPA Horizons 2025 Report. Retrieved from http://www.aicpa.org/research/cpahorizons2025/Pages/CPAHorizons2025.aspx

2. $\quad$ Antonakis, J. \& House, R.J. (2002). Transformation and charismatic leadership: The road ahead. In B. J. Avolio, \& F. J. Yammarino, (Eds.), The Full-Range Leadership Theory: The Way Forward, Transformational and Charismatic Leadership: The Road Ahead (Vol. 2 of Monographs in Leadership and Management), (pp. 3-33). Amsterdam: JAI, An Imprint of Elsevier Science.

3. Aristotle. (1962). Nichomachean ethics. Translated by M. Ostwald. Indianapolis: Bobbs-Merrill.

4. Avolio, B. J., Bass, M.B. (1999). Re-examining the components of transformational and transactional leadership using the Multifactor Leadership Questioner. Journal of Occupational and Organizational Psychology, 72(4), 441-462.

5. Avolio, B. J., Bass, M.B. (2004). Multifactor Leadership Questionnaire, Manual and Sample Set ( ${ }^{\text {rd }}$ ed.). Redwood City, CA: Mind Garden.

6. Avolio, B. J., Bass, M. B., Walumbwa, F., \& Zhu, W. (2004). MLQ Multifactor Leadership Questionnaire: Technical report, leader form, rater form, and scoring key for MLQ Form $5 x$-Short (3rd ed.). Redwood City, CA: Mind Garden.

7. Utah Association of CPAs. (2009). 2010 Resource \& Membership Directory, September 4, 2009.

8. $\quad$ Bass, B. M. (1985). Leadership and performance beyond expectations. New York: Free Press.

9. Bass, B. M. (1997). Does the transactional-transformational leadership paradigm transcend organizational and national boundaries? American Psychologist, 52(2), 130-139. 
10. Bass, B. M., \& Avolio, B. J. (Eds.) (1994). Improving organizational effectiveness through transformational leadership. Thousand Oaks, CA: Sage Publications.

11. Bass, B. M., \& Avolio, B. J. (2004). MLQ Multifactor Leadership Questionnaire for Research Web Data Collection. Retrieved from http://www.mindgarden.com/products/mlqr.htm

12. Bryant, S. E. (2003). The role of transformational and transactional leadership in creating, sharing, and exploiting organizational knowledge. The Journal of Leadership and Organizational Studies, 9(4), 32-44.

13. Campbell, D. T., \& Stanley, J. C. (1963). Experimental and quasi-experimental designs for research. Boston: Houghton Mifflin Company.

14. Conger, J. A., Kanungo, R. N., \& Menon, S. T. (2000). Charismatic leadership and follower effects. Journal of Organizational Behavior, 21(7), 747-767.

15. Creswell, J. W. (2005). Educational research: Planning, conducting, and evaluating quantitative and qualitative research. Upper Saddle River, NJ: Pearson/Merrill Prentice Hall.

16. De Hoogh, A. H. B., Den Hartog, D. N., \& Koopman, P.L. (2005). Linking the big five-factors of personality to charismatic and transactional leadership; perceived dynamic work environment as a moderator. Journal of Organizational Behavior, 26(7), 839-865.

17. Derue, D., Nahrgang, J. D., Wellman, H., \& Humphrey, S. E. (2011). Trait and behavior theories of leadership: An integration and meta-analytic test of their relative validities. Personnel Psychology, 64(1), 7-52).

18. Dvir, T., Avolio, B. J., \& Shamir, B. (2002). Impact of transformational leadership on follower development and performance: a field experiment. Academy of Management Journal, 45(4), 735-744.

19. Dumdum, U. R., Lowe, K. B., \& Avolio, B. J. (2002). A meta-analysis of transformational and transactional leadership correlates of effectiveness and satisfaction: An update and extension (pp. 36-66). In B. J. Avolio \& F. J. Yammarino (Eds.), Transformational and charismatic leadership: The road ahead. Oxford, U.K.: Elsevier Science.

20. Early, J., \& Davenport, J. B. (2010). Desired qualities of leaders within today's accounting firms. The CPA Journal, 80(3), 59-62.

21. El-Ramly, Y. (April, 2012). Keep the best and brightest. Journal of Accountancy, 18.

22. Flesher, D. L., \& Gabre, H. G. (2009). NABA: Forty years of growth. Journal of Accountancy, 208(6), 5660.

23. Friedman, H., Langbert, M., \& Giladi, K. (2000). Transformational Leadership. National Public Accountant, 45(3), 8-11.

24. George, D., \& Mallery, P. (2003). SPSS for Windows step by step: A simple guide and reference, (11.0 update, 4th ed.). Boston, MA: Allyn and Bacon.

25. Gold, L. (2007). How far to the top? Accounting Today, 21(18), 35-37.

26. Hui, C. H., Chiu, W. C. K., Yu, P. L. H., Cheng, K., \& Tse, H. H. M. (2007). The effects of service climate and the effective leadership behaviour of supervisors on frontline employee service quality: A multi-level analysis. Journal of Occupational and Organizational Psychology, 80(1), 151-172.

27. Jung, D. I. (2001). Transformational and transactional leadership and their effects on creativity in groups. Creativity Research Journal, 13(2), 185-195.

28. Lowe, K. B., Avolio, B. J., \& Dumdum, U. R. (2013). Don't you love it when a plan comes together? Update on meta-analytic findings for transformational and transactional leadership. In Avolio, B.J., \& Yammarino, F.J. (Eds.) Transformational and charismatic leadership: The road ahead $\left(2^{\text {nd }} e d\right.$. $-10^{\text {th }}$ Anniversary Edition) (Vol. 5 of Monographs in Leadership and Management). Bingley, UK: Emerald/JAI.

29. Lowe, K. B., Kroeck, K. G., \& Sivasubramaniam, N. (1996). Effectiveness of correlates of transformational and transactional leadership. Leadership Quarterly, 7(3), 385-425.

30. Mannarelli, T. (2006). Accounting for leadership: Charismatic, transformational leadership through reflection and self-awareness. Accountancy, Ireland, 38(6), 46-48.

31. MLQ. (2004). Multifactor Leadership Questionnaire (3 ${ }^{\text {rd }}$ ed.). Manual and Sampler Set. Retrieved from https://www.mindgarden.com

32. Nahavandi, A. (2006). The art and science of leadership (4 ${ }^{\text {th }}$ ed.). Upper Saddle River, NJ: Pearson Education.

33. Northouse, P. G. (2010). Leadership: Theory and practice $\left(5^{\text {th }}\right.$ ed.). Los Angeles: Sage.

34. Scalleta, T. (2006). Beyond process improvement: The pathway to process-based management. CMA Management, 80(4), 22/25. 
35. Stringer, L. (2006). The link between the quality of the supervisor-employee relationship and the level of the employee's job satisfaction. Public Organization Review, 6(2), 125-142.

36. Viator, R. E. (2001). The relevance of transformational leadership to nontraditional accounting services: Information systems assurance and business consulting. Journal of Information Systems, 15(2), 99-125.

37. Vigilante, B. (2005). Women at full throttle. Journal of Accountancy, 200(4), 76-77.

38. Watkins, M. D. (2009). Picking the right transition strategy. Harvard Business Review, 87(1), 46-53.

39. Zenger, J. H., \& Folkman, J. R. (2009). The extraordinary leader: Turning good managers into great leaders. New York: McGraw Hill. 


\section{NOTES}

